\title{
EFFECT OF FLOWER SHAPES AND NECTAR GUIDES ON THE BEHAVIOUR OF FORAGING HONEYBEES
}

\author{
by
}

\author{
J. B. FREE \\ (Rothamsted Experimental Station, Harpenden, Herts., England) \\ (With I Figure) \\ (Rec. I2-VI-I970)
}

\section{INTRODUCTION}

Sprengel (1793) first drew attention to the various lines, spots and blotches of contrasting colour on the petals of many flowers and suggested that they guided insects to the nectaries. Lix (1957) showed that these 'nectar guides' also often have scents that contrast with the scents of the other parts of the petals. Flowers without nectar guides that he investigated always had scent guides with increasingly stronger scents toward the centres of the flowers. Probably many such flowers have nectar guides visible to bees but not to man, because Dhumer (1963) and KugLer ( 1963) demonstrated that ultra-violet nectar guides are more common than those of other colours. Lex pointed out that the pollen of insect-pollinated flowers always has a strong scent, in contrast to the poorly scented pollen of wind- or birdpollinated flowers.

Studies with honeybees (Zerrain, I931) and bumblebees (KuGr.er, I943; MANning, 1956) indicate that nectar guides increase the attractiveness of a flower; also, studies with the hawk moth, Macroglossum stellatarum (KNOLL, 1926) and bumblebees (KugLer, 1930, 1943; MaNNiNG, 1956) indicate that they also guide a visitor to the nectaries, although there is disagreement as to whether bumblebee visits are directed to the centre of a radially symmetrical flower model without nectar guides.

The responses honeybees make to nectar guides and flower shape has now been investigated.

\section{METHOD}

Honeybees were trained to forage at tables ( $40 \mathrm{~cm}$ high) each with a metal framework and a top of two sheets of glass ( $30 \mathrm{~cm}$ square) between which were scattered ten circular yellow cardboard discs or 'model flowers' $(3 \mathrm{~cm}$ diameter). Drops of sugar syrup, put on the glass above each disc, were replenished as necessary during the training period. When about 20 to 30 bees were foraging regularly, these training models were replaced by eight 
models of each of two different shapes or patterns but with similar areas. These were arranged in a $4 \times 4$ square so that each row and each column contained two models of each type. The top sheet of glass was then replaced by a clean one without syrup. During the next 30 minutes the bees that landed at each model were counted; the table was rotated at intervals to prevent the bees becoming conditioned to landing at any particular site.

The models were yellow and any patterns on them were marked in blue lines, about $0.5 \mathrm{~mm}$ wide. Petween each test bees were allowed to collect syrup from above plain circular models. Several different sites were used. In some experiments attempts were made to record the parts of models on which bees landed. They moved too rapidly to determine the parts to which they responded while still airborne.

Any deviation from the above procedure is noted below.

\section{Eiffect of colour.}

\section{RESULTS}

In experiment $\mathrm{I}$ bees trained to $30 \mathrm{~mm}$ circular yellow models were given the choice of these or $30 \mathrm{~mm}$ circular blue models; they always landed (69 times) on the yellow, never on the blue ( I'<0.00I). The pronounced discrimination by the bees in this experiment was as expected (see v. Frisch, I967), and illustrates the validity of the method.

Effect of odour.

Bees were trained to circtiar yellow models, each with a small plastic dish ( $8 \mathrm{~mm}$ diameter) containing methyl heptanone in its centre. They were then presented with yellow models with plastic vials, half containing methyl heptanone and half empty. They preferred the models with the training odour (Table I).

\section{TABI.E I}

No. times bees landed at

$\begin{array}{lccc} & \begin{array}{c}\text { Models with } \\ \text { methyl heptanone } \\ \text { odour }\end{array} & \begin{array}{c}\text { Models without } \\ \text { odour }\end{array} & \text { P } \\ \text { Expt. 2. } & 253 & & \\ \text { Expt. 3. } & \text { I68 } & \text { I I2 } & <0.001 \\ & & 63 & <0.00 \text { I }\end{array}$

Fxperiment 4 was similar except that the vials previously empty now contained benzyl acetate; 288 bees landed at the models with methyl heptanone but only 47 at the models with benzyl acetate. Proportionally fewer bees than in experiments 2 and 3 landed at models without the methyl heptanone 
training odour ( $\mathrm{P}<\mathrm{O} .00 \mathrm{I}$ for each comparison), presumably indicating that a strange odour was positively avoided, whereas absence of an odour merely made the models less attractive.

Relative effect of odour and colour.

In experiment 5, bees were trained to visit the yellow models and methyl heptanone odour and given a choice of : (a) blue models with methyl heptanone odour or (b) yellow models with benzyl acetate odour. I) first $3^{\circ}$ minutes, 82 bees landed at $(a)$ and $5^{8}$ at $(\mathrm{b})(\mathrm{P}<0.05)$; observation was continued for another 30 minutes during which 50 bees landed at (a) and $3 \mathrm{I}$ at $(\mathrm{b})(\mathrm{P}<0.05)$. Hence the training odour was more effective than the training colour.

Effect of model size.

Bees that were given the choice of plain circular models of different sizes showed no preference for the size of model presented during training (Table 2 ). even in experiment I 2 when they were trained to collect syrup from $30 \mathrm{~mm}$ models for three days while go mm models without syrup were also present.

\section{TABLE 2}

No. times bees landed on models of different sizes

\begin{tabular}{|c|c|c|c|c|c|}
\hline \multirow{3}{*}{ Expt. No. } & \multicolumn{4}{|c|}{ Size of disc (mm) } & \multirow[b]{2}{*}{$\mathrm{P}$} \\
\hline & 20 & 30 & 40 & 90 & \\
\hline & I4 & 6 & & & $>0.05$ \\
\hline 7 & 34 & 36 & & & " \\
\hline 8 & 12 & 12 & & & $"$ \\
\hline 9 & & 48 & 48 & & $"$ \\
\hline 10 & & $3 I$ & I9 & & $"$ \\
\hline II & & 39 & & 40 & " \\
\hline 12 & & 28 & & $4 \mathrm{I}$ & נ \\
\hline 13 & & 29 & & 45 & $"$ \\
\hline 14 & & 36 & & 23 & $"$ \\
\hline
\end{tabular}

The number visiting the size used during training is given it italics.

Effect of shape.

Bees were trained to $30 \mathrm{~mm}$ circular models and tested with circular, triangular, square, petaloid (Fig. I. 'A') and star-shaped (Fig. I. 'B' \& 'C') models of approximately the same area. The results (Table 3 ) indicate that models with disruptive outlines were the more attractive, but increasing the number of rays of a star from 6 to $\mathrm{I} 2$ did not increase visits. In subsequent tests the stars used had six rays (model ' $\mathrm{B}$ '). Because no preference was 


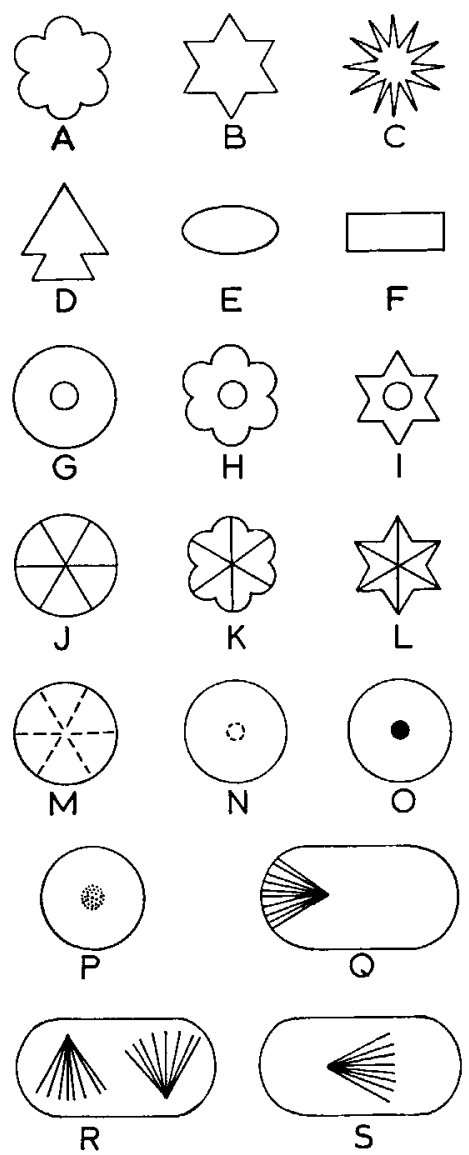

Figure I. Models used during the experiments. Not to scale.

given to the circular models, the slightly greater attractiveness of the petaloid to the star-shaped models was probably not from any shape preference obtained during training.

All the above models were radially symmetrical. The bees were now made to choose between radially symmetrical and bilaterally symmetrical models (including arrow shaped, model ' $\mathrm{D}$ '; oval, model ' $\mathrm{E}$ '; and oblong, model ' $\mathrm{F}$ '). The results (Table 4) show that radially symmetrical models are preferred to bilaterally symmetrical ones. The bees had been trained to collect syrup from oblong models before experiments $3 \mathrm{I}$ and 32 , and had collected syrup from oblong models in the presence of squares without syrup before experiments 33 and 34 ; however, this training did not reverse the usual preference for radially symmetrical models. 


\section{TABLE 3}

No. times bees landed at models of different shape

Expt. No.

$\begin{array}{lc} & \text { Circle } \\ \text { I5 } & 25 \\ \text { 16 } & 24 \\ & \text { Circle } \\ \text { 17 } & 17 \\ & \text { Circle } \\ \text { I8 } & 13 \\ & \text { Square } \\ \text { 19 } & 63 \\ & \text { 12-rayed star ('C') } \\ 20 & 59 \\ & \text { 6-rayed star ('B') } \\ 21 & 23 \\ 22 & 60\end{array}$

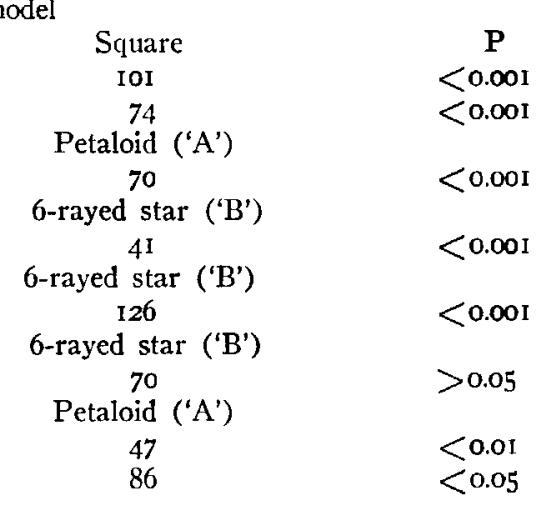

Effect of nectar guides.

Tests were made of bees' reactions to circular, petaloid and star-shaped models that were either plain yellow, or yellow with blue 'nectar guides' as rings (models ' $G$ ', ' $H$ ' and ' $I$ ') or radiating lines (models ' $J$ ', ' $K$ ' and 'L’). Bees landed much more on models with nectar guides (Table 5); ring and radiating guide lines seemed equally effective in inducing them to do so. Before experiment 38 , bees had been trained to a circular model with radiating guide lines, but this made no apparent difference to their later responses.

\section{TABLE 4}

No. times bees landed at radially and bilaterally symmetrical models

\section{Expt. No.}

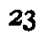

24

25

26

27

28

29

30

31

32

33

34

Shape of model

Circle
32
54
Square
56

Star ('D')

132

Circle

36

I06

Square

84

102

69

78

158

84

\section{Triangle}

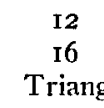

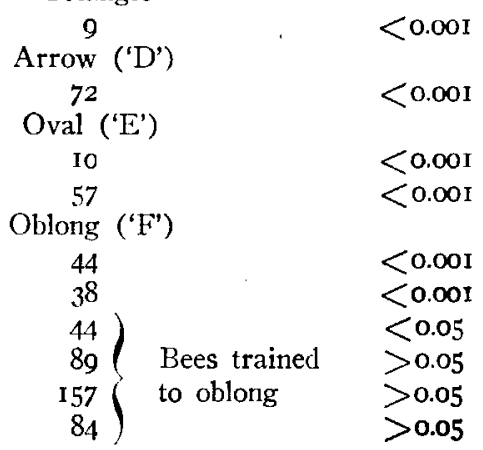


TABLE 5

No. times bees landed on plain discs and discs with nectar guides

\begin{tabular}{|c|c|c|c|}
\hline Expt. No. & Plain Circle & $\begin{array}{l}\text { Circle with ring } \\
\text { nectar guide (' } G \text { ') }\end{array}$ & $P$ \\
\hline 35 & Plain circle & $\begin{array}{l}38 \\
\text { Circle with radiating } \\
\text { guide lines ('J') }\end{array}$ & $<0.001$ \\
\hline 36 & I 2 & 47 & $<0.001$ \\
\hline 37 & 8 & 51 & $<0.001$ \\
\hline 38 & $\begin{array}{c}\mathrm{I} 4 \\
\text { Plain petaloid ('A') }\end{array}$ & $\begin{array}{l}{ }^{73} \\
\text { Petaloid with ring } \\
\text { nectar guide (' } \mathrm{H} \text { ') }\end{array}$ & $<0.001$ \\
\hline 39 & Plain petaloid ('A') & $\begin{array}{l}42 \\
\text { Petaloid with radiating } \\
\text { guide lines ('K') }\end{array}$ & $<0.05$ \\
\hline 40 & 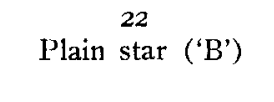 & $\begin{array}{c}46 \\
\text { Star with ring } \\
\text { nectar guide ('I') }\end{array}$ & $<0.01$ \\
\hline $4 \mathrm{I}$ & $\begin{array}{l}4^{6} \\
\text { Plain star ('B') }\end{array}$ & $\begin{array}{l}76 \\
\text { Star with radiating } \\
\text { guide lines (' } L \text { ') }\end{array}$ & $<$ o.or \\
\hline 42 & $4 \mathrm{I}$ & 66 & $<0.02$ \\
\hline 43 & 40 & 53 & $>0.05$ \\
\hline
\end{tabular}

In all the other experiments, bees had as usual been trained to $30 \mathrm{~mm}$ circular models.

In additional experiments, drawing twice as many lines on some models as on models ' $\mathrm{J}$ ', ' $\mathrm{K}$ ' and ' $\mathrm{L}$ ' (Fig. I) did not increase their attractiveness. Similarly, petaloid or star-shaped models with guide lines drawn along the middle of the petals (as in ' $\mathrm{K}$ ' and ' $\mathrm{L}$ ') had the same attractiveness as models with guide lines drawn between the petals.

In three of four experiments, guide lines that were continuous lines (models ' $\mathrm{J}$ ', ' $G$ ' and ' $O$ ') were less attractive than broken lines or a cluster of dots (models ' $M$ ', 'N' and 'P'). (Table 6).

\section{TABLE 6}

No. times bees landed on models with nectar guides drawn as

\begin{tabular}{|c|c|c|c|c|}
\hline Experiment No. & & $\begin{array}{l}\text { Continuous } \\
\text { lines }\end{array}$ & $\begin{array}{l}\text { Broken lines } \\
\text { or dots }\end{array}$ & $\mathrm{P}$ \\
\hline 44 & $\begin{array}{l}\text { Circles with radiating } \\
\text { guide lines (' } \mathrm{J} \text { ' and ' } \mathrm{M} \text { ') }\end{array}$ & 39 & 116 & $<0.001$ \\
\hline $\begin{array}{l}45 \\
46\end{array}$ & Circles with ring nectar & $\begin{array}{l}43 \\
42\end{array}$ & $\begin{array}{r}137 \\
39\end{array}$ & $\begin{array}{l}<0.001 \\
>0.05\end{array}$ \\
\hline 47 & $\begin{array}{l}\text { Circles with nectar guides } \\
\text { in centre (' } \mathrm{O} \text { ' and ' } \mathrm{P} \text { ') }\end{array}$ & 88 & 122 & $<0.02$ \\
\hline
\end{tabular}


Relative effect of flower shapes and nectar guides.

Bees were given the choice of circular models without nectar guides and petaloid or star-shaped models with nectar guides (Table 7 ). The relative

\section{TABLE 7}

No. times bees landed on models with and without nectar guides

$\begin{array}{cccc}\text { Elain circle } & \begin{array}{c}\text { Star-shaped } \\ \text { without nectar } \\ \text { guide }\end{array} & \begin{array}{c}\text { Eodel with guide } \\ \text { lines ('L') }\end{array} & P \\ \text { Experiment } 48 & \begin{array}{c}3 \\ \text { Plain circle } \\ \text { without nectar } \\ \text { guide }\end{array} & \begin{array}{c}\text { Petaloid model } \\ \text { with guide lines }\end{array} & <0.001 \\ \text { Experiment } 49 & 5 & (\text { 'K') } & \\ & & \text { I57 } & <0.001\end{array}$

proportion of visits made to the petaloid and star-shaped models in experiments 48 and 49 was greater than in experiments 17 and 18 respectively, which were similar except that the models did not have nectar guides $(\mathrm{P}<0.05$ and $\mathrm{P}<0.00 \mathrm{I})$.

When round and star-shaped models, both with radiating guide lines ( $J$ ' and ' $L$ ') were compared, the star-shaped models were visited more often (Table 8), but the response to circular models with guide lines ('J') was similar to that of star-shaped models without (' $\mathrm{B}$ ').

\section{TABLE 8}

No. times bees landed on

$$
\begin{aligned}
& \text { Circle with } \\
& \text { radiating guide } \\
& \text { lines (' } \mathrm{J} \text { ') }
\end{aligned}
$$

Experiment 50

Experiment 5I
19

Circle with radiating guide lines $(\mathrm{J})$

$$
\begin{aligned}
& \text { Star with } \\
& \text { radiating guide } \\
& \text { lines (' } L \text { ') }
\end{aligned}
$$

$$
\begin{gathered}
36 \\
\text { Star without } \\
\text { nectar guides } \\
\text { ('B') }
\end{gathered}
$$$$
52
$$

$$
\mathbf{P}
$$

$>0.05$

Effect of odour left by bees.

Use was made of the preference bees show for a segmented model with nectar guides to find whether odour left by the bees on the glass immediately above a model affects later visits. Plain circular models and star-shaped models with radiating guide lines (' $L$ ') were arranged in a $4 \times 4$ latin square so that opposite halves of the square were mirror images of each other, and, by moving the covering sheet of glass through a $90^{\circ}$ angle, the 
parts of glass immediately above the models covered a different kind of model than previously.

During the first ten minutes of the experiment nearly all bees alighted on the stars (Table 9). The sheet of glass was then moved through $90^{\circ}$ and during the second ten minutes the circles received many visits. During the third ten minutes, the greater visual attraction of the stars was again manifest.

\section{TABLE 9}

No. times bees landed at

Plain circles

Experiment $52 \quad$ First 10 minutes Second 10 minutes Third so minutes

1
25

Stars with radial guide lines

86

26

38

Therefore, it is apparent that once a model has been visited its chances of receiving additional visits are increased. Hence this method may exaggerate the differences between the visual attractiveness of models of different shape and pattern, but perhaps bee odour may play a corresponding role in nature. Moreover, because the results with models are usually so clear cut, and the more crucial experiments have given similar results on repetition, this defect in the technique is not serious.

Influence of model shape and nectarguides on alighting positions of the bees.

Bees were classified according to whether they first alighted in the centre of a model, at its edge, or elsewhere on it. Few bees landed at the centres of plain models or models with radiating guide lines ('J' and ' $\mathrm{L}$ ') (Table Io,

\section{TABLE ro}

\section{No. times bees landed at}

Experiment No.

53

54

55

56

57

58
Plain circle

Circle with radial guide lines ('J')

Plain star ('B')

Star with radial guide lines ('L')

Plain circle

Circle with ring nectar guide ('G')

Plain petaloid shape

Petaloid shape with ring nectar guide (' $\mathrm{H}$ ')

Plain star ('B')

Star with ring nectar guide ('T')

Plain star ('B')

Star with ring nectar guide ('I')
Centre Edge Elsewhere

$\begin{array}{rrr}\mathbf{0} & \mathbf{3} & 4 \\ \mathbf{2} & \mathbf{2 2} & \mathbf{2 7} \\ \mathbf{0} & \mathbf{3 6} & \mathbf{3} \\ \mathbf{0} & \mathbf{3 2} & \mathbf{2 0} \\ \mathbf{0} & \mathbf{2} & \mathbf{0} \\ \mathbf{2 6} & 4 & \mathbf{5} \\ \mathbf{0} & \mathbf{6} & \mathbf{1 6} \\ \mathbf{9} & 16 & 16 \\ \mathbf{0} & 24 & \mathbf{2 2} \\ \mathbf{6} & \mathbf{2 7} & 39 \\ \mathbf{0} & \mathbf{1 5} & \mathbf{3 1} \\ \mathbf{2 1} & \mathbf{2 1} & \mathbf{1 3}\end{array}$


Exp. 53 and 54). However, the presence of ring nectar guides increased the proportion of bees landing at the centres of circular models (' $G$ ') (Table IO, Exp. 55: $\mathrm{P}<0.05$ ) but not of petaloid or star-shaped ones (' $\mathrm{H}$ ' and ' $\mathrm{I}$ ') (Exp. 56 and 57 ). In fact, a greater proportion of bees landed at the centre of the circular than at the centre of the petaloid or star-shaped models with nectar guides $(\mathrm{P}<0.001$ for each comparison).

In contrast to previous experiments, during which they had been trained to collect syrup from a plain circular model, in experiment 58 , bees were trained to collect syrup from a star-shaped model with a ring nectar guide ('I'). Later, proportionally more of these bees went to the centres of such models than to the centres of star-shaped models without nectar guides ('B') $(\mathrm{P}<0.05)$. The proportion that went to the centres of the star-shaped models with ring nectar guides (' $\mathrm{I}$ ') was also greater than in Experiment 57 in which bees had not been first trained to them.

Although the $30 \mathrm{~mm}$ models are similar in size to many natural flowers, records of where the bees landed on them were inevitably somewhat subjective. To obtain more precise results, $90 \mathrm{~mm}$ models were later used; bees landing within $10 \mathrm{~mm}$ of the edge of a model were recorded as visiting the edge; bees landing in an imaginary circle of $30 \mathrm{~mm}$ diameter in the centre of a model were recorded as visiting the centre; the remaining bees were recorded as landing elsewhere. Nectar guides only increased the responses to the centre slightly, if at all (Table I I).

TABI.E I I

No. times bees landed at

\begin{tabular}{|c|c|c|c|c|c|}
\hline & & Centre & Edge & Elsewhere & $\mathrm{P}$ \\
\hline Experiment 59 & $\begin{array}{l}\text { Plain circle } \\
\text { Circle with radial } \\
\text { guide lines ('I') }\end{array}$ & 3 & I I & I9 & $>0.05$ \\
\hline Experiment 60 & $\begin{array}{l}\text { Plain circle } \\
\text { Circle with radial } \\
\text { guide lines ('J') }\end{array}$ & 13 & $4 \mathrm{I}$ & I4 & $>0.05$ \\
\hline Experiment 61 & $\begin{array}{l}\text { Plain circle } \\
\text { Circle with radial } \\
\text { guide lines ('J') }\end{array}$ & 21 & 14 & 0 & $<0.05$ \\
\hline
\end{tabular}

Next, bees were trained to collect from a small, constantly replenished drop of syrup in the centre of each plain $90 \mathrm{~mm}$ model and, in experiments 62 and 63 (Table 12), proportionally more bees went to the centres than the edges of models with nectar guides ('J') than did to models without nectar guides. A greater proportion also went to the centre of the models with nectar 
TABLE 12

No. times bees landed at

\begin{tabular}{|c|c|c|c|c|c|}
\hline & & Centre & Edge & Elsewhere & $\mathbf{P}$ \\
\hline \multirow[t]{2}{*}{ Experiment 62} & Plain circle & 2 & 39 & 4 & \\
\hline & $\begin{array}{l}\text { Circle with radial } \\
\text { guide lines (' } \mathrm{J})\end{array}$ & 67 & $4 \mathrm{I}$ & Io & $<0.001$ \\
\hline \multirow[t]{2}{*}{ Experiment 63} & Plain circle & o & 25 & 5 & \\
\hline & $\begin{array}{l}\text { Circle with radial } \\
\text { guide lines (' } J \text { ') }\end{array}$ & 50 & 35 & 3 & $<0.001$ \\
\hline
\end{tabular}

guides in experiments 62 and 63 than in experiment $6 \mathrm{I}$, in which bees had not been trained to visit the centres of models but, as usual, to collect syrup from drops scattered over the surfaces of the models $(\mathrm{P}<\mathrm{O} .00 \mathrm{I}$ for each comparison).

Finally, bees were trained to collect from the centres of $90 \mathrm{~mm}$ models with radial guide lines ('J'). In later experiments, 64 and 65 , most visits were to the centres of these models (Table I3) and proportionally more than in experiments 62 and $63(\mathrm{P}<\mathrm{O} .00 \mathrm{I})$.

\section{TABI.E I3}

No. times bees landed at

\begin{tabular}{|c|c|c|c|c|}
\hline & & Centre & Edge & Elsewhere \\
\hline \multirow[t]{2}{*}{ Experiment 64} & Plain circle & o & 0 & $o$ \\
\hline & $\begin{array}{l}\text { Circle with radial } \\
\text { guide lines ('J') }\end{array}$ & 32 & I & 3 \\
\hline \multirow[t]{2}{*}{ Experiment 65} & Plain circle & o & 5 & o \\
\hline & $\begin{array}{l}\text { Circle with radial } \\
\text { guide lines ('J') }\end{array}$ & 53 & I6 & 4 \\
\hline
\end{tabular}

Because so few bees visited plain circles when they were presented simultaneously with circles bearing nectar guides, in a further test plain circles only were presented after the bees had been trained to collect from the centre of circles with radiating guide lines (' $\mathrm{J}$ '). All 56 recorded landings were to the edges only.

\section{'Guiding' function of nectarguide pattern.}

Experiments 64 and 65 had indicated that, once bees had been trained to collect food from the centres of models with converging guide lines, they later used the nectar guide pattern when trying to locate it. The following experiments investigated this further.

In experiment 66 , bees were trained to $90 \mathrm{~mm}$ models and then presented with four oblong models ( 140 by $90 \mathrm{~mm}$ ) which had converging guide lines 
occupying a third of the model ai one end only (' $Q$ '). Most bees landed on the area of a model with the guide lines but did not select the point where the lines converged (Table I4).

\section{TABLE I4}

No. times bees landed at

Area with guide lines

Area without guide lines

Experiment No.

Not where the

Where the guide

guide lines met

$\begin{array}{rrrr}66 & 3 & 25 & 8 \\ 67 & 47 & 78 & 11 \\ 68 & 30 & 16 & 6\end{array}$

The bees were then allowed to collect syrup for one hour only from the points where the guide lines of ' $R$ ' type models met, and the original ' $Q$ ' models were then returned (Exp. 67). Despite the differences between these two types of model, the bees landed on the test models more often in the areas with nectar guides $(\mathrm{P}<0.05)$ and at the points where the guide lines met $(\mathrm{P}<0.05)$ than in the previous experiment.

In experiment 68 , bees were trained to collect syrup from the point where the guide lines of model ' $Q$ ' met for several hours before being presented with similar models without syrup. Response to this point was even greater than in experiment 67 ( $\mathrm{P}<\mathrm{O}$.0Or), confirming that it depended on previous conditioning.

The training situation in experiment 60 was as in experiment 68 , but afterwards the bees were presented with a choice of $90 \mathrm{~mm}$ plain circular models and $90 \mathrm{~mm}$ circular models with radial nectar guides ('J'). Despite the differences between the models used in training and testing, the responses

TABLE I 5

No. times bees landed at

$\begin{array}{llccc}\text { Experiment 69 } & \begin{array}{l}\text { Plain circle } \\ \text { Circle with radial } \\ \text { guide lines }\end{array} & 0 & \text { I I } & \text { I } \\ & 85 & \text { I4 } & 4\end{array}$

to the centres of the models with nectar guides were as in experiments 64 and 65 (Table I3) where testing and training models were identical.

Experiment 70 was in some ways the reverse of experiment 69 as bees were trained to collect syrup from the centre of a $90 \mathrm{~mm}$ circular model with radiating nectar guides (' $J$ ') and then presented with ' $Q$ ' models (Table I6). Although the bees concerned had no previous experience of these models, 
more $(\mathrm{P}<0.05)$ landed at the points where the guide lines met than when trained to a plain circular model (Exp. 66, Table I4), but fewer $(\mathrm{P}<0.00 \mathrm{I})$ than when trained to a ' $Q$ ' model (Exp. 68, Table I4).

\section{TABLE I6}

No. times bees landed at

Area with guide lines

Where the guide Not where the guide

lines met lines met

Experiment 70

I7

36

14

During the final experiments on the 'guiding' function of nectar guides, a rectangular model ('S') with converging lines in the centre third was used. In experiment $7 \mathrm{I}$, bees were trained to a plain circular model, and afterwards the points at which they landed on four ' $S$ ' models were recorded (Table I7). More bees went to the nectar guide area of a molel than to the remaining two thirds: but there was no preference for any particular part of the nectar guide.

In experiments 72 and 73 , bees were trained to collect syrup from the area of ' $S$ ' models where the nectar guides were wide apart, but their response to this area was not subsequently increased (Table i7). However, when, in

\section{TABLE I 7}

No. times bees landed at

Experiment No.

Area with guide lines
Where nectar Furtherest Central
lines met from where third
guide lines
met

Areas without guide lines

Nearest to Furtherest where guide from where lines met guide lines met

$\begin{array}{rrrrrr}\mathbf{7 1} & 34 & 29 & 26 & 33 & 33 \\ \mathbf{7 2} & \mathbf{5 1} & \mathbf{5 8} & 31 & 17 & 14 \\ \mathbf{7 3} & \mathbf{5 0} & \mathbf{3 8} & 42 & \mathbf{1 6} & \mathbf{2 2} \\ \mathbf{7 4} & \mathbf{4 5} & \mathbf{1 4} & \mathbf{8} & 9 & 8 \\ \mathbf{7 5} & \mathbf{7 1} & \mathbf{1 2} & \mathbf{1 4} & 8 & 15 \\ \mathbf{7 6} & \mathbf{9 2} & \mathbf{2 1} & \mathbf{2 4} & 7 & 17\end{array}$

experiments 74 and 75 , bees were trained to collect syrup from where the guide lines converged, their subsequent response to this area was much greater and about the same as in experiment 76 in which bees had, before being tested, been trained to the centre of a large circular model with radiating guide lines ('J') (Table I7). 
Response to indication of depth.

Various attempts were made to give an illusion of depth to models and to see whether the bees responded to it. In experiments 77 to 80 , bees were trained to collect syrup from $90 \mathrm{~mm}$ white circular models. They were then tested with models that had either no markings, or models with black circles in their centres (' $\mathrm{O}$ '), or models that had been given an impression of depth and shadow either by concentric rings that increased in darkness toward their centres, or by black dots that were spaced more closely towards their centres. In all experiments, the proportion of visits to the centres was greater for models with black central circles ('O'), althotgh they were visited less than models with other types of nectar guides (Table I8).

Before experiments 81,82 and 83 , the bees were trained to take syrup from the centres only of the types of models on which they were later tested; this increased the response to the centre of all the models used (Table I8). In experiment $8 \mathrm{I}, \mathrm{I} 52$ of the $\mathrm{I} 64$ bees that landed at the edges of the models with black dots that were increasingly closely spaced towards their centres (' $U$ ') then walked to the centre of the model, whereas only 2 of the 7 bees that landed on the edge of the models with central black circles ('O') did so $(\mathrm{P}<\mathrm{O} .00 \mathrm{I})$. In experiments 82 and 83.37 out of 40 and $5 \mathrm{I}$ out of 55 respectively of the bees that landed at the edges of ' $U$ ' models walked to their centres.

In a final experiment (No. 84) to try to discover whether the bees would respond to an illusion of depth, a Petunia flower was photographed from above and prints of it (about $90 \mathrm{~mm}$ diameter) were made showing either the original dark centre of the flower, or a superimposed centre of the same shade of grey as the petals. However, few bee visits ( 7 and Io\% respectively) were to the centres of 'flowers' of either type.

\section{DISCUSSION ANI) CONCIUUSIONS}

The colour of a model was a prime distinguishing feature, but its size was not, and models nine times the area of the training model or only half its area, were visited as often as the training model itself. This indicates that a mutant with flowers larger or smaller than usual will be visited as readily as other flowers of the population, provided that it is equally attractive in other ways. However, when a training scent was used, it was preferred to colour as a discriminating factor, and confirms the importance of odour (e.g. Kucler, I943; Manning, 1956) in the initiation of new species of floral plants.

My results also confirm (see HERTZ, I929 and ZERRAHN, I934, on honeyBehaviour XXXVII 
TABLE I8

No. visits bees made to

Difference in the proportion visiting the centres of the models

Experiment

No.

Centre

Edge

Elsewhere

$\mathrm{P}$

77 Plain circle

o

24

2

Circle with central

black circle

23

I2

$<0.001$

78 Circle with central

black circle

II

$<0.001$

Circle with rings

increasingly dark

42

35

toward centre

79 Circle with central

black circle

I3

8

$<0.001$

Circle with dots increasingly closely

I8

67

I8

spaced toward centre

80 Circle with central

black circle

12

9

$<0.001$

Circle with dots increasingly closely

8I Circle with central

black circle

Circle with dots increasingly closely spaced toward centre

82 Circle with central

black circle

28

2

3

Circle with dots increasingly closely 37

40 $<0.001$ spaced toward centre

I

$<0.001$

Circle with dots increasingly closely 47 55 $<0.001$ spaced toward centre 
bees, Kugler, 1930, 1943, and Manning, 1956, on bumblebees) that nectar guides and a disruptive pattern increase the attractiveness of a model. The effect of both guide lines and segmentation of a model was additive, but increasing either beyond a certain amount did not increase the honeybees' response. Even when bees are trained to a simple model, they prefer a complex one, although training to a complex model increases the response to it. Hence, any changes in these features that a mutant shows are unlikely to be of much consequence, unless either the general population or the mutant lacks them entirely. An example of the latter circumstance was obtained by SCORA (r964), who found that a mutant of Monarda punctata, that had a corolla without spots, in contrast to the usual row of spots on the lower lip of the corolla, was not visited by bees and wasps when grown among a normal population.

Butler (I95I) working with honeybees, and Manning (1956) with bumblebees, found that the edge of a disc, which contrasted with its background, received most responses. My results support theirs, but not those of KUGLER (1943), who reported that bumblebees have an innate tendency to seek food in the centre of a model of regular shape, and that nectar guides are unnecessary. However, KUGLER used tubes containing sugar syrup, the round openings of which were flush with the surfaces of his models; perhaps the tubes themselves helped to guide the bees to the models' centres.

MANNing ( I956) found that nectar guide lines on a test model decreased the proportion of responses bumblebees made to its edge, irrespective of whether the training model had guide lines or not. In contrast, I found that when nectar guide lines were added to a model the response of honeybees to its centre was increased only slightly, if at all; neither did they direct the attention of bees, that had already alighted, towards the model's centre. It was only after bees had been trained to collect food in the centres of models with nectar guides that the lines had any guiding function; but such training was rapid. Moreover, it was easier to train bees to an area where the guide lines converged than to where they diverged maximally. This may merely reflect the greater optical stimulation the bees received where the lines were close together.

A black central area was most effective in directing honeybees to a model's centre, and, although the response to the centre of such a model was increased after training, the initial response of untrained bees was considerable. However, in contrast to bumblebees (KugLer, I943; Manning, 1956), honeybees showed no response to an effect of depth. Perhaps this, and the preference of honeybees for radially symmetrical models, reflects differences in the types of flower preferred by honeybees and bumblebees. LEPPIK (1953) 
recorded the insects visiting about 500 species and varieties of wild and garden flowers, and found that bumblebees mostly visited zygomorphic flowers whereas honeybees mostly visited radiate flowers. It is perhaps significant that nectar guides that are visible to man are commoner on zygomorphic flowers (KUGLER, 1930) whose nectaries are probably more difficult to find; probably the nectar guides of such flowers have a more pronounced guiding function. Hence, any change in the symmetry and depth of a flower could result in a different population of insects visiting it and so contribute toward ethological isolation (see Grant, I949; FREE, I966). It would be interesting to study the responses of flower-visiting insects other than bumblebee: and honeybees to the shapes and nec'ar guides of flowers.

\section{SUMMARY}

I. Honeybees were trained to collect syrup from coloured dises and then presented with a choice of 'model' flowers.

2. The colour of a model was an important distinguishing feature, but its scent was even more important. A foreign odour made the models less attractive than no odour.

3. The size of a training model did not influence the size of model later chosen, but the bees preferred radially symmetrical to bilaterally symmetrical models, and models with a disruptive outline to circular models, even though trained to circular ones.

4. Adding nectar guides to a model increased its attractiveness, independently of conditioning; dotted lines were more attractive than continuous lines, and a group of dots was more attractive than a black circle in the centre of a model. Adding a disruptive outline to a model similarly incrcased attractiveness and effects of a disruptive outline and nectar guide lines were additive. However, a limit was soon reached in which more guide lines or further segmentation failed to increase attractiveness.

5. Bees showed no preference to alight in the centres of circular models, and preferred the edges of the petaloid or star-shaped models.

6. Nectar guide lines had a directing function only when the bees had learned to seek food at a particular site in relation to them. Training to a point where nectar guide lines converged was quickly achieved, and could be transferred to models of other types. A nectar guide ring in the centre of a model sometimes slightly increased the proportion of visits to its centre, but conditioning was again necessary to obtain much effect.

7. Bees without previous training were attracted to a black central area, and this was still more effective after training. The bees' behaviour was not affected by attempts to give models an illusion of depth.

\section{REFERENCES}

Butler, C. G. (I95I). The importance of perfume in the discovery of food by the worker honeybee (Apis mellifera L.). - Proc. R. Soc. B. p. 403-4I3.

Daumer, K. (I958). Blumenfarben, wie sie die Bienen sehen. - Z. vergl. Physiol. 4 I. p. 49-I IO.

FrEE, J. B. (1966). The foraging behaviour of bees and its effect on the isolation and speciation of plants. - In: Reproductive biology and taxonomy of vascular plants, ed. J. G. Hawkes, London: Pergamon Press, p. 76-92.

FrISCH, K. von (1967). The dance language and orientation of bees. - London, Oxford Univ. Press. 
Grant, V. (I949). Pollination systems as isolating mechanisms in angiosperms. - Evolution 3, p. 82-97.

Hertz, Mathilde (1929). Die Organisation des optischen Feldes bei der Biene II. Z. vergl. Physiol. II, p. 107-145.

Knoll, F. (1926). Insekten und Blumen. - Abhandl. Zool.-Bot. Gesellsch. Wien I2, I-646.

Kugler, H. (r930). Blütenökologische Untersuchungen mit Hummeln I. - Planta Io, p. $220-280$.

— (I943). Hummeln als Blütenbesucher. - Ergebn. Biol. 19. p. I43-323.

(1963). UV-Musterungen auf Blüten und ihr Zustandekommen. - Planta 59, p. $296-329$.

Leprik, E. E. (1953). The ability of insects to distinguish number. - Amer. Nat. 87 (835), p. 229-236.

LEx, T. (I954). Duftmale an Blüten. - Z. vergl. Physiol. 36, p. 212-234.

Manning, A. (I956). The effect of honey-guides. - Behaviour 9, p. II4-I 39.

- (1957). Some evolutionary aspects of the flower constancy of bees. - Proc. Roy. Physic. Soc. 25, p. 67-7I.

SCORA, R. W. (1964). Dependency of pollination on patterns in Monarda (Labiatae). - Nature 204, p. IOII-IOI2.

Sprengel, C. K. (I793). Das entdeckte Geheimnis der Natur im Bau und in der Befrüchtung der Blumen. - Berlin, Vieweg.

Zerrahn, Gertrud (1934). Formdressur und Formunterscheidung bei der Honigbiene. Z. vergl. Physiol. 20, p. I17-150.

\section{RESUME}

Des Abeilles furent dressées à récolter du sirop sur des disques colorés et présentés parmi un choix du modèle en forme de fleurs.

La couleur du modèle était un signe distinctif important mais son odeur l'était bien davantage. Les modèles aux odeurs inhabituelles attiraient moins les Abeilles que ceux qui n'avaient aucune odeur.

La dimension des modèles de dressage n'avait pas plus d'influence sur le comportement des Abeilles que celle des modèles présentés par la suite; cependant, elles prétéraient les modèles à face simple à ceux à double faces, et les modèles à contours irréguliers à ceux circulaires, même si elles avaient été dressées avec ces derniers.

Indépendamment de ces conditions, l'apport de nectar rendait le modèle particulièrement attirant. Les faces irrégulières attiraient davantage que les faces unies, de même qu'une surface mouchetéc plaisait plus que celle ayant un cercle noir au centre du modèle. Le nectar-guide était d'autant plus apprécié que les faces du modèle étaient hachurées et produisaient des effects de lignes brisées. Cependant, à partir d'une certaine limite, elles n'entraînaient pas un effet meilleur vers le guide.

Les Abeilles ne montraient pas de goût particulier à se poser au centre des modèles à formes circulaires, elles préféraient ccux à forme de pétales ou en étoiles.

Le Nectar-guide t'eut vraiment son utilité que lorsque les Abeilles en comprirent la relation avec leur recherche de nourriture.

Le dressage à détecter le nectar-guide se faisait rapidement et pouvait ensuite être répété sur des modèles d'autres types.

Un dépôt de Nectar-guide au centre d'un modèle a parfois augmenté légèrement la proportion des vols vers ce centre, mais il n'était pas obligatoire pour obtenir plus d'effet.

Les Abeilles n'ayant pas subi d'entraînement préalable étaient attirée par une zone noire centrale et cette attraction restait encore effective après leur dressage. Leur conduite n'était pas affectée en donnant au modèle une apparence de profondeur. 